Rok XIV (2019) | 2 (28) | s. 29-42

https://doi.org/10.12797/LV.14.2019.28.02

Przemysław Łozowski $\bullet$

Uniwersytet Marii Curie-Skłodowskiej, Lublin

prloz@wp.pl

\title{
W POSZUKIWANIU KONTINUUM GRAMATYKI I LEKSYKI: PRZYKŁAD GRAMATYKALIZACJI
}

Słowa kluczowe: kontinuum słownictwa i gramatyki, gramatykalizacja a leksykalizacja, językoznawstwo kognitywne

Keywords: continuum of vocabulary and grammar, grammaticalization versus lexicalization, cognitive linguistics

\section{Wstęp}

W niniejszym artykule usiłujemy odpowiedzieć na pytanie, co to znaczy, że w myśl jednej z tez językoznawstwa kognitywnego - „leksykon i gramatyka tworzą kontinuum” (Langacker 2009: 20) lub że „tworząc kontinuum z leksykonem, gramatyka nie istnieje autonomicznie” (Langacker 2017: 77)․․ Za stosowne źródło materiału ilustracyjnego i argumentacyjnego uznajemy zjawisko gramatykalizacji, to właśnie tutaj bowiem elementy leksykalne mają przechodzić w elementy gramatyczne. Kontinuum chcemy rozumieć tak, jak je przedstawia Ronald Langacker (1987, 2008 (wyd. pol. 2009), 2016, 2017), a gramatykalizację tak, jak ją określił Jerzy Kuryłowicz (1965/1975). Do zrozumienia Langackerowskiej koncepcji kontinuum (cz. 4) prowadzi nas krytyczna prezentacja kilku wybranych odczytań tego pojęcia (cz. 3), a przedstawienie gramatykalizacji ograniczamy do zacytowania definicji J. Kury-

1 O ile nie podano inaczej, cytaty ze źródeł anglojęzycznych podajemy we własnym tłumaczeniu. 
łowicza i podania kilku przykładów (cz. 2). Z dwóch tytułowych pojęć kluczowym problemem badawczym jest dla nas raczej zrozumienie kontinuum niż dyskusja nad tym, czym jest, czym nie jest i na czym polega gramatykalizacja ${ }^{2}$.

Pretekst do poniższych rozważań czerpiemy z lektury szeregu najnowszych prac, w których pojęciu kontinuum (także: ciagłość) towarzyszą różne interpretacje. Na przykład Emilia Kubicka (2018: 87) rozumie je jako brak możliwości rozgraniczenia, Aleksander Kiklewicz (2017: 56) jako synkretyzm, czyli, jak rozumiemy, współwystępowanie różnych jakości w jednej całości, Aleksandra Niewiara (2017: 236) jako ciąg ewolucyjny (pojęć i nazw), Anetta Luto-Kamińska (2017: 145) jako przeciwieństwo ewolucji postępującej na zasadzie etapowości, Dorota Filar (2015: 9) jako otwartość danego zbioru na nowe elementy, Piotr Sobotka i Magdalena Żabowska (2017: 115, 124) jako trwanie w czasie (stąd: „ciągłość historyczna”), Alina Kępińska i Izabela Winiarska-Górska (2015: 237) jako niezmienność i trwałość (stąd: „ciągłość językowa” i fakty językowe, „które nie podlegały zmianom w historii”) - autorki powołują się przy tym na stwierdzenie Barbary Skargi, że „to continuum takie, jak je określa matematyka" (ibid.).

A zatem gdybyśmy mieli szukać odpowiedzi na pytanie, czym jest kontinuum, do dyspozycji pozostaje szereg rozwiązań już stosowanych w językoznawstwie, w tym modele zdroworozsądkowe, historyczne, biologiczne i matematyczne. Za zasadne uznajemy omówić niektóre z nich i zwizualizować ich konsekwencje dla badań nad gramatykalizacją (cz. 3), a także potraktować jako punkt wyjścia prezentacji koncepcji R. Langackera (cz. 4) $)^{3}$.

2 Jednym z najnowszych przejawów tego, jak można rozumieć gramatykalizację - wprawdzie bez odniesień do Jerzego Kuryłowicza - jest studium Krzysztofa Hwaszcza i Hanny Kędzierskiej (2018a, 2018b).

3 Jednemu z Recenzentów zawdzięczamy zwrócenie uwagi na fakt, że bliskie nam rozumienie kontinuum (zob. cz. 4) występowało już w niemieckich i rosyjskich gramatykach funkcjonalnych w latach 8o. XX w., a i teraz można je odnaleźć we wspólnym udziale elementów gramatycznych i leksykalnych w reprezentacji syntaktycznej w tzw. leksykalno-funkcjonalnym modelu składni (J. Bresnan 2015). Nie podzielamy tego stanowiska i za niefortunną, choć typową dla rozwoju nauki zbieżność nazw uznajemy funkcjonalizm dawnych gramatyków-strukturalistów i obecnych leksykalistów-składniowców oraz funkcjonalizm Ronalda Langackera i innych kognitywistów. Dopóki przedmiotem analizy pozostają elementy i relacje systemu językowego bez odwołań pozajęzykowych, dopóty domniemany funkcjonalizm ma co najwyżej wymiar wewnątrzsystemowy - język jest funkcjonalny, bo jest systemem celowym sam w sobie. Dla kognitywistów funkcjonalizm to poszukiwanie pozajęzykowego (doświadczeniowego, poznawczego, kulturowego) umotywowania dla zjawisk językowych - język jest funkcjonalny, bo jako symbol ludzkiego doświadczenia wyraża ludzkie poznanie. To przekłada się na rozumienie kontinuum. W tym sensie kontinuum w kontekście systemu znaków dowolnych (arbitralnych) to zgoła coś innego niż kontinuum w kontekście zbioru symboli jako znaków niedowolnych (koniecznych). 


\section{Gramatykalizacja jako zmiana językowa}

J. Kuryłowicz definiuje gramatykalizację w sposób następujący:

Gramatykalizacja polega na tym, że dany morfem, rozszerzając zakres użycia, zmienia swoją charakterystykę z leksykalnej na gramatyczną lub z mniej gramatycznej na bardziej gramatyczną, jak na przykład w sytuacji, kiedy rostek słowotwórczy staje się końcówką fleksyjną (Kuryłowicz 1965/1975: 52)4.

Jest więc gramatykalizacja zmianą językową - w obrębie ustalonych relacji między ustalonymi elementami języka następuje zmiana, która skutkuje wygenerowaniem wyznaczników gramatycznych z - za Zuzanną Topolińską (2018: 44) - „[argumentów] zapisan[ych] w [...] strukturze semantycznej, w tzw. znaczeniu leksykalnym" lub nadaniem istniejącym wyznacznikom gramatycznym jeszcze bardziej gramatycznego (czyli: jeszcze mniej leksykalnego) charakteru. A zatem J. Kuryłowicz przewiduje dwa przypadki szczegółowe gramatykalizacji, niemniej oba mające związek z ubożeniem znaczeń leksykalnych i wzbogacaniem znaczeń gramatycznych.

Przywołana przez niego zmiana, w której „rostek słowotwórczy staje się końcówką fleksyjną", to sytuacja, w której dany element wyjściowy jest natury gramatyczno-leksykalnej: nie jest wprawdzie niezależnym słowem, ale ma jednak zabarwienie leksykalne o tyle, o ile służy tworzeniu nowych słów, a z drugiej strony ta jego zdolność słowotwórcza jest jego funkcją gramatyczną. Ten element - już w jakimś stopniu gramatyczny - ulega dalszej gramatykalizacji, tzn. zostaje jeszcze bardziej pozbawiony znaczeń leksykalnych i staje się jeszcze bardziej gramatyczny ${ }^{5}$. Można to zilustrować pochodzeniem angielskiej końcówki fleksyjnej -ed z protoindoeuropejskiej końcówki słowotwórczej *-to-. Ta pierwsza służy dzisiaj do tworzenia form czasu przeszłego (i imiesłowu biernego) czasowników słabych (jak w love - loved-loved 'kochać' albo talk - talked - talked 'rozmawiać'), a ta druga umożliwiała tworzenie przymiotników oznaczających aspekt dokonania w stosunku do formy wyjściowej tych przymiotników, którą były czasowniki, szczególnie zaś imiesłów bierny, czyli czwarta forma czasowników (tzw. supinum). I tak w zależności od koniugacji i rodzaju powstawały przymiotniki odczasownikowe o znaczeniu imiesłowów biernych.

4 Chociaż sformułowana przed laty, definicja J. Kuryłowicza nie straciła na ważności i wciąż odgrywa rolę punktu odniesienia w badaniach nad gramatykalizacją. Pisze o tym Przemysław Łozowski (2008: 2.2), a ostatnio przypominają to Dorota Filar i P. Łozowski (2018, 2019).

5 Pozostaje do wyjaśnienia, co J. Kuryłowicz ma na myśli, mówiąc, że „dany morfem [...] zmienia swoją charakterystykę [...] z mniej gramatycznej na bardziej gramatyczną” (podkr. - P.Ł.). Jeden z Recenzentów widzi to tak: istnieje zespół właściwości jednostek gramatycznych i są wśród nich takie, które spełniają wszystkie wymogi gramatyczności, ale są też takie, które spełniają tylko część wymogów; właśnie w strefie przejściowej są takie jednostki, których znaczenie nie jest wystarczająco odrealnione, np. formanty słowotwórcze. Niewykluczone, że J. Kuryłowiczowi o to chodzi w jego definicji gramatykalizacji. 
Na przykład w przypadku czasownika 1. koniugacji amo - amare - amavi - amatum ('kocham - kochać - kochałem - kochany') czwarta forma, amatum, to imiesłów bierny, który staje się przymiotnikiem odczasownikowym amatus - amata - amatum odpowiednio dla rodzaju męskiego, żeńskiego i nijakiego ${ }^{6}$. Jeżeli więc w łacinie końcówka -tus/taltum pełni funkcję gramatyczną w sensie słowotwórczym (czasownik > przymiotnik), to w angielskim jest już tylko końcówką fleksyjną (czasownik > $>$ czasownik). Innymi słowy, o ile w zasobach łaciny znajdujemy wyznacznik gramatyczny (jeszcze) o zabarwieniu leksykalnym, to w angielszczyźnie widzimy już tylko formant czysto gramatyczny pozbawiony śladów pierwotnych znaczeń leksykalnych, taki, który, jak powiedziałaby E. Kubicka, „uzyskuje autonomię formalną i treściową względem konstrukcji, z której powstał” (2018: 101), ale jest „bardzo ubogi [...] semantycznie" (ibid.: 84) 7 .

Z kolei pierwszy wariant gramatykalizacji w rozumieniu J. Kuryłowicza, czyli sytuacja, kiedy wyznacznik całkowicie leksykalny (tj. pozbawiony znaczeń gramatycznych) przechodzi w wyznacznik całkowicie gramatyczny (tj. pozbawiony znaczeń leksykalnych), to przypadek always. Dzisiejsze angielskie słowo always 'zawsze' jest historyczną kontynuacją staroangielskiego wyrażenia ealneweg (dzisiaj byłoby to all (the) way) 'cała droga, wszystkie drogi', wzbogacanego na początku XV w. o końcowy oznacznik dopełniacza -s. Gramatykalizacja w tym przypadku polega na tym, że pierwotny wyznacznik leksykalny - ealneweg - uległ takiej rekonceptualizacji, że $\mathrm{z}$ wyrażenia $\mathrm{z}$ domeny przestrzeni stał się wyrażeniem $\mathrm{z}$ domeny czasu: 'jeżeli coś zdarza się wszędzie, dosł. na przestrzeni całej drogi/ścieżki, to zdarza się zawsze’. Innymi słowy, w swoim pierwotnym przestrzennym znaczeniu always był niezależny od struktury, a raczej: od relacji gramatycznych w zdaniu/wypowiedzeniu, i znaczył to, co „mówił”, a mówił 'wszędzie'. W tym sensie był „leksykalny”. Jeżeli dzisiaj always znaczy 'zawsze', to nie sposób się tego dopatrzeć w tym, co ten przysłówek mówi.

Mamy tu ilustrację wnioskowania poznawczego wielokrotnie opisywanego w literaturze lingwistycznej jako metafora typu CZAS TO PRZESTRZEŃ: wyrażenia odnoszące się do przestrzeni bazują na doświadczeniach bardziej podstawowych, fizykalnych, konkretnych niż wyrażenia odnoszące się do czasu (który nie poddaje się bezpośredniemu poznaniu zmysłowemu). Przestrzeń jako domena źródłowa na-

6 Podobnie dzieje się w przypadków pozostałych trzech koniugacji łacińskich: w 2. koniugacji, np. video - videre - vidi - visum 'widzę - widzieć - widziałem - widziany', w 3 . koniugacji, np. audio - audire - audivi - auditum 'słyszę - słyszeć - słyszałem - słyszany', i w 4. koniugacji, np. lego - legere - legi - lectum 'czytam - czytać - czytałem - czytany' - czwarta forma jest podstawą do tworzenia przymiotników odczasownikowych, a w każdym przypadku umożliwia to formant słowotwórczy -tus/-tal-tum.

7 Naturalnie do rozstrzygnięcia pozostaje kwestia, czy i na ile imiesłów bierny angielskich czasowników słabych może funkcjonować jako przymiotnik odczasownikowy. Forma loved w He is a much loved and respected person '(on) jest osobą uwielbianą i szanowaną' jest z pewnością przymiotnikiem, ale w He is loved jest, co najwyżej, imiesłowem biernym użytym w funkcji przymiotnika. 
daje więc strukturę docelowej domenie czasu. W tym sensie znaczenia przestrzenne są bardziej pierwotne, powiedzmy, bardziej leksykalne niż znaczenia temporalne, które pojawiają się jako wtórne i są, powiedzmy, bardziej zgramatykalizowane. Gramatykalizacja w tym przypadku wiąże się bowiem z przekształceniem znaczeń leksykalnych, względnie niezależnych od relacji strukturalnych, w znaczenia bardziej gramatyczne, jakie dana forma zdradza dopiero w relacji z innymi elementami struktury (por. Filar, Łozowski 2018, 2019) ${ }^{8}$.

Już te dwa przykłady zachęcają do myśleniu o języku w kategoriach kontinuum jeżeli wyznaczniki leksykalne przechodzą w wyznaczniki gramatyczne, to granica między leksyką i gramatyką musi być płynna, nieostra i stopniowalna. Jak zatem rozumieć kontinuum wyznaczników leksykalnych i gramatycznych?

\section{Kontinuum: przegląd modeli}

Zaczynamy zatem od krótkiego przeglądu wybranych koncepcji kontinuum. Pierwszej dostarczają nam definicje słownikowe słowa kontinuum. Definicja w SJP jest tutaj typowa: 'ciągły, uporządkowany zbiór nieskończonej liczby elementów przechodzących płynnie jeden w drugi'9. Gdybyśmy ją mieli odnieść do gramatykalizacji, otrzymalibyśmy kontinuum typu ciągu linearnego od wyznaczników ekstremalnie (maksymalnie, wyłącznie) leksykalnych do wyznaczników ekstremalnie (maksymalnie, wyłącznie) gramatycznych:

Ilustracja 1. Kontinuum leksyki i gramatyki - wizualizacja 1

\section{LEKSYKagramaTYKA}

8 Jak łatwo można zauważyć, stosujemy odmienne od powszechnego rozumienie procesu leksykalizacji, którą uznajemy za proces odwrotny do gramatykalizacji (zgodnie zresztą z oryginalną intencją samego J. Kuryłowicza (!) (zob. Kuryłowicz 1965/1975: 52-53)). W myśl tradycyjnej interpretacji always byłoby zapewne potraktowane jako przykład leksykalizacji, podobnie jak polskie jednym słowem i innymi słowy (Kubicka 2018), celem i drogą (Wasilewska 2018) czy przeto (Sobotka, Żabowska 2017). Istotnie i niewątpliwie z pojawieniem się niezależnego słowa always wzbogaciła się angielska leksyka. Ale nastąpiło to w wyniku gramatykalizacji, przynajmniej w rozumieniu J. Kuryłowicza. Zwróćmy uwagę na to, co badacze przypisują wspomnianym polskim wyrażeniom - „ulega[ją] dalszej redukcji”, „służą [...] do porządkowania większych całości tekstu”, „pełnią nową funkcję - są metatekstowe” (Kubicka 2018: 88), „[występują] w funkcji przyimkowej” (Wasilewska 2018: 274), „przeto to spójnik wnioskowania [...] powstał[y] z połączenia przyimka *per 'przez' i pierwotnie wskazującego zaimka ${ }^{\star}$ to" (Sobotka, Żabowska 2017: 120). Zauważmy, że to wszystko jest charakterystyczne dla skutków gramatykalizacji (więcej o tym w: Filar, Łozowski 2018, 2019).

9 Brak haseł kontinuum i continuum w SJPD, NSJPDun, NSJP. 
Trzy podstawowe atrybuty kontinuum - ciągłość, uporządkowanie i płynność widać jeszcze lepiej w definicji ISJP: 'ciąg elementów równomiernie rozłożonych na jakiejś skali, nie rozdzielonych wyraźnie od siebie’. Jak rozumiemy, płynność z definicji w SJP tutaj otrzymuje (bardziej kontrowersyjne) brzmienie - równomiernośc, a brak wyraźnego rozdzielenia dotyczy elementów sąsiadujących ze sobą. Tak należy odebrać przykład, którym redaktorzy ilustrują znaczenie kontinuum: „Z jednej strony malarstwo przedstawieniowe, $z$ drugiej abstrakcyjne. A między tymi biegunami rozciąga się kontinuum form i kształtów". Zauważmy, że nasza ilustracja 1 pokazuje i płynność przechodzenia leksyki w gramatykę, i równomierny rozkład domniemanych kolejnych elementów leksykalnych i gramatycznych (kolejne litery są rzeczywiście pomniejszane/powiększane o tę samą miarę). Ale ta równomierność to tylko niezamierzone uproszczenie graficzne - nie należy się spodziewać, by przechodzenie leksyki w gramatykę odbywało się w dokładnie takich samych odstępach. O nich możemy mówić w przypadku zbioru liczby całkowitych, w którym między kolejnymi elementami odkładana jest ta sama miara - 1, 2, 3, 4, 5, 6 itd. Niemniej przykład podany w samym ISJP nastręcza problemów, ponieważ nie ilustruje podanej definicji. Trudno mianowicie zgodzić się z tym, by przejście form i kształtów malarstwa przedstawieniowego $\mathrm{w}$ stronę form i kształtów malarstwa abstrakcyjnego miało się odbywać $\mathrm{z}$ taką samą matematyczną równomiernością co narastanie kolejnych elementów w zbiorze liczb całkowitych. Rezygnujemy zatem z równomierności jako atrybutu kontinuum, tym bardziej że ISJP jest jedynym źródłem leksykograficznym $\mathrm{z}$ tych branych tutaj pod uwagę, które równomierność uważa za cechę kontinuum.

Tak czy inaczej, model kontinuum przedstawiony na il. 1 i derywowany z definicji w SJP i w ISJP nie znajduje zastosowania w przypadku gramatykalizacji, ponieważ (i) zakłada odrębność gramatyki i leksyki, a ich wzajemne przenikanie sprowadza do ,jednorazowego" przeniknięcia leksyki w gramatykę w jakimś konkretnym punkcie kontinuum, (ii) nie uwzględnia współistnienia znaczeń gramatycznych i leksykalnych w tych samych wyznacznikach oraz (iii) suponuje całkowity brak gramatyki w jednym końcu kontinuum i całkowity brak leksyki w drugim, co - jeśli miałoby zostać odniesione do globalnego rozwoju języka - może oznaczać wyłącznie leksykalny charakter języka w momencie jego narodzin i wyłącznie gramatyczny charakter języka w momencie jego śmierci.

Uwzględniając te zastrzeżenia, stwierdzamy, że bardziej realny byłby schemat, w którym ubożeniu znaczeń leksykalnych towarzyszy równoczesne wzbogacanie znaczeń gramatycznych i odwrotnie: 
Ilustracja 2. Kontinuum leksyki i gramatyki - wizualizacja 2

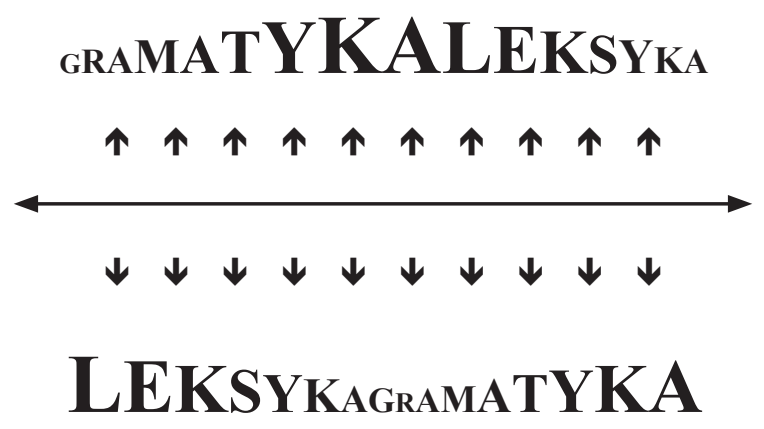

Czy słowniki języka polskiego dostarczają wsparcia leksykograficznego dla tak rozumianego kontinuum, czyli dla modelu, który byłby (i) nielinearny, (ii) niejednokierunkowy i (iii) niejednowymiarowy?

Pozostałe dwa słowniki przywoływane tutaj na potrzeby wstępnej analizy znaczeń terminu kontinuum podają po dwie definicje, przy czym bez względu na to, czy kontinuum definiowane jest z pozycji filozoficzno-matematycznej, ogólnej czy przenośnej, w przeciwieństwie do ISJP i podobnie do SJP nie sugeruje się $\mathrm{w}$ nich, by elementy tworzące kontinuum różniły się między sobą o wartość równomierną:

USJP: 1. 'ciągłość, całość, coś, czego poszczególne elementy łączą się ze sobą tak, że nie można ich rozdzielić; 2. (filoz./mat.) 'ciągły, uporządkowany zbiór nieskończonej liczby elementów przechodzących jeden w drugi'.

PSWP: 1. (filoz./mat.) 'ciągły, uporządkowany, nieskończony zbiór elementów, które przechodzą jeden w drugi'; 2. (przenośnie) 'łańcuch, pasmo, ciągłość, w której nie można wyróżnić poszczególnych elementów'.

O ile znaczenia z zakresu filozofii i matematyki nie wnoszą do naszej dyskusji nic nowego, o tyle pozostałe dwie definicje wzbogacają ją o odpowiedź na pytanie, jaki charakter ma następowanie po sobie kolejnych elementów kontinuum. Już wiemy, że nie jest to z zasady następstwo na zasadzie równomierności. Podpowiedź w USJP i PSWP jest jednoznaczna: to następowanie odbywa się na zasadzie płynności i nieostrości granic kolejnych elementów. Z jednej strony elementy po sobie następują, tworząc układ progresywny (tzn. że każdy kolejny element jest odmienny od poprzedniego), ale z drugiej strony zachowują tyle łączliwości, że „nie można ich rozdzielić” (USJP) czy „nie można wyróżnić poszczególnych elementów” (PSWP).

Zwraca uwagę przykład ilustrujący 2. znaczenie w PSWP: „Dialekty pomorsko-połabskie nad Bałtykiem i Morzem Północnym stanowiły kontinuum dialektalne - 
łańcuch dialektów, z których sąsiednie niemal niepostrzegalnie przechodziły jedne w drugie, a dopiero ogniwa skrajne różniły się wyraźniej”. Wyrażenie niemal niepostrzegalnie sugeruje taki rodzaj ciągłości elementów w następstwie szeregowym, że zmiany zdają się możliwe do uchwycenia dopiero na tle całego ciągu, całego szeregu od jednego ekstremum do drugiego. To ważna informacja dla nas, ponieważ przypomnijmy - w swojej definicji gramatykalizacji J. Kuryłowicz wyróżnia dwa przypadki: jeden jest globalny (daje się zauważyć w perspektywie całego kontinuum) i skokowy (leksykalny > gramatyczny), a drugi jest lokalny (obejmuje zawężony wycinek kontinuum) i gradialny (mniej gramatyczny > bardziej gramatyczny). To, że element już gramatyczny (indoeuropejski rostek słowotwórczy -to-) traci jeszcze więcej ze swojej strukturalnej niezależności i przez to staje się jeszcze bardziej gramatyczny (angielska końcówka fleksyjna -ed), nie przeszkadza temu, że można wyróżnić kategorię wyznaczników leksykalnych i kategorię wyznaczników gramatycznych jako dwóch ekstremów tego samego kontinuum i stwierdzać zmiany radykalne (angielskie always).

Jedno z możliwych odczytań terminu kontinuum, jakie przytaczamy we wstępie (Kępińska, Winiarska-Górska 2015: 237), kieruje naszą uwagę w stronę matematyki. Jednakże w naszej ocenie matematyczna koncepcja kontinuum nie może posłużyć ani jako model, ani jako ilustracja ciągłości gramatyki i leksyki. Dlaczego? Przez kontinuum matematycy rozumieją moc zbioru liczb rzeczywistych, czyli - mówiąc językiem niematematycznym - ilość, liczebność, pojemność czy zasobność zbioru liczb wymiernych (takich, które można przedstawić za pomocą ułamka zwykłego; np. -24, 3, 112) i niewymiernych (takich, których nie można przedstawić za pomocą ułamka zwykłego; np. liczba pi i $\sqrt{2}$ ). Ta ilość liczb rzeczywistych to oczywiście nieskończoność, a zatem kontinuum, czyli moc zbioru, liczb rzeczywistych obejmuje nieskończenie wiele liczb, wszystkie uporządkowane w sposób ciągły według relacji mniejszości/większości. W tym momencie tak rozumiane kontinuum można przedstawić jako ciąg elementów od minus nieskończoności do plus nieskończoności:

Ilustracja 3. Kontinuum leksyki i gramatyki - wizualizacja 3

$\begin{array}{ccc}-\infty & 0 & +\infty\end{array}$

Taki model kontinuum (jako nieskończonej liczby elementów) stanowi problem dla analizy gramatykalizacji. Oprócz linearności i jednokierunkowości w modelu przyjmuje się, że (i) dany zbiór nie ma początku ani końca, (ii) nie ma zbioru elementów przejściowych (tu: takich, które byłyby jednocześnie ujemne i dodatnie), a liczba 0 stanowi radykalną/ostrą cezurę między elementami jednego (ujemne) i drugiego rodzaju (dodatnie) oraz (iii) porządek elementów po lewej stronie elementu granicz- 
nego (liczba 0) stanowi lustrzane odbicie porządku elementów po prawej stronie elementu granicznego. Gdybyśmy więc mieli odnieść te trzy obserwacje do relacji między leksyką i gramatyką w obrębie gramatykalizacji, musielibyśmy przyjąć tezę o ich nieskończoności, kategorialnej ostrości (jednoznaczności) i symetryczności. Tymczasem nie o nieskończoność zbiorów wyznaczników leksykalnych i gramatycznych tutaj chodzi, ale o ich otwartość, nie o ostrość granic kategorii, ale o ich płynność, i nie o odwzorowanie symetryczne, ale o ekwiwalentność.

W tej części przedstawiliśmy szereg możliwych odczytań kontinuum, próbując odnieść doraźne ustalenia do przebiegu i natury gramatykalizacji jako zmiany językowej. W części kolejnej poddajemy bliższej analizie rozumienie, jakie przypisuje kontinuum R. Langacker, wkraczając na grunt rozważań już wyłącznie językoznawczych.

\section{Kontinuum w gramatyce kognitywnej Ronalda Langackera}

Jedną z podstawowych tez swojego językoznawstwa R. Langacker sprowadza do pojęcia nondiscreteness ${ }^{10}$, które w fundamentalnym dziele z $1987 \mathrm{r}$. opisuje następująco:

Wiele z tego, co odnajdujemy w języku, jest kwestią stopnia. Relacje językowe nie są niezmiennie sprawą zaszufladkowania typu „wszystko-albo-nic”, tak jak kategorie językowe nie zawsze dają się definiować jednoznacznie, czy też nigdy nie mogą mieć nieostrych granic (Langacker 1987: 14).

Nondiscreteness jest więc dla R. Langackera synonimem ciągłości, płynnych granic i stopniowalności, a discreteness - nieciągłości, ostrych granic i odrębności.

10 Langackerowskie terminy discreteness i nondiscreteness najchętniej tłumaczylibyśmy odpowiednio jako nieciagłość i ciagłość, głównie dlatego, że Langacker stosuje je zamiennie z discontinuity i continuity, a te jednoznacznie należy identyfikować z parametrem ciągłości lub jej braku. Niemniej pozostawiamy je $\mathrm{w}$ oryginalnym angielskim zapisie $\mathrm{z}$ dwóch powodów. Po pierwsze, (non)discreteness odnosi się do specyficznego rodzaju ciągłości, takiego, który polega na braku jednoznacznej granicy między poszczególnymi elementami, a zatem jest jakimś złożeniem ciągłości, płynności i stopniowalności. Po drugie, w polskim tłumaczeniu dzieła Langackera, powszechnie uznawanego za najnowsze kompendium wiedzy o jego gramatyce kognitywnej (Langacker 2008; wydanie w języku polskim - 2009), oba terminy oddane zostały niekonsekwentnie jako dyskretność i niedyskretność (np. 2009: 30), ale częściej jako odrębność i ciagłość (ibid.: 292, 298, 386, 717). Nie ułatwia to polskiemu czytelnikowi odbioru zamierzonego znaczenia angielskich oryginałów. Dodatkowo mylące jest tłumaczenie odnośnego przymiotnika - (non)discrete - jako (nie)dyskretny (np. ibid.: 26-30), przez co otrzymujemy - w polskim tłumaczeniu - dyskretne jednostki, dyskretne symbole, dyskretne struktury, a to przywodzi na myśl inne słowo angielskie o identycznym brzmieniu i niemal identycznej pisowni - discreet. Ten drugi termin oznacza 'dyskretny' właśnie w sensie spodziewanym i dosłownym, czyli 'taki, który dochowuje tajemnic i taktownie nie wnika w czyjeś prywatne sprawy' (SJP). Ponieważ Langackerowi na pewno nie chodzi o dyskretność w sensie dyskrecji, zapraszamy do samodzielnego odbioru zamierzonych znaczeń (non)discreteness. 
Język ma naturę ciągłą (nondiscrete), co oznacza, że elementy, kategorie, relacje, jakie odnajdujemy w języku, przechodzą stopniowo jedne w drugie.

W przywołanej pracy R. Langackera pojęcie kontinuum pojawia się jako jeden z czterech czynników, aspektów czy - jak chce autor - „powiązanych wymiarów” nondiscreteness ${ }^{11} \mathrm{i}$ jest definiowane $\mathrm{w}$ kontraście do discreteness:

Discreteness [...] zakłada konieczność istnienia ostrych granic [ang. sharp distinctions] między ogólnymi klasami zjawisk językowych, przez co implikuje się, że te klasy różnią się między sobą z natury rzeczy, a zatem w dużej mierze powinny być one opisywane niezależnie od siebie. Alternatywa typu nondiscreteness utrzymuje tymczasem, że te klasy przechodzą jedna w drugą pod względem wielu różnych parametrów. Razem zaś [klasy te] tworzą nieprzerwane spektrum (lub pole) możliwości, których podział [ang. segregation] na wydzielone całości blokowe musi w końcu okazać się zabiegiem nienaturalnym [ang. artifactual] (ibid.: 18).

A zatem R. Langackerowi chodzi o takie rozumienie kontinuum, które cechowałaby gradacja, a nie segregacja/segmentacja, spektrum zjawisk, a nie wydzielone klasy zjawisk, a przypadki pośrednie czy przejściowe byłyby równie uprawnione co przypadki ekstremalne. Langacker wylicza kilkanaście przykładów nieuprawnionej segregacji językoznawczej na ściśle wydzielone kategorie zjawisk językowych, a wśród nich ten najbardziej nas interesujący, tj. dychotomiczny podział na gramatykę i leksykę ${ }^{12}$.

Tej domniemanej dychotomii - jako jedynej zresztą - Langacker poświęca swoją dalszą wypowiedź. Zacytujmy obszerne fragmenty w ramach poszukiwania odpowiedzi na pytanie, czym jest język, jeśli ma mieć naturę kontinuum:

Dobrą ilustracją discreteness jest tradycyjny podział na morfemy leksykalne i gramatyczne (lub, innymi słowy, na wyznaczniki leksykalne [ang. content words] i wyznaczniki gramatyczne [ang. function words]). Jeżeli ograniczymy się jedynie do takich form, jak z jednej strony giraffe 'żyrafa', encyclopedia 'encyklopedia', upholster 'obijać/tapicerować', inquisitive 'ciekawski' czy fastidiously 'skrupulatnie' oraz, z drugiej strony, do takich form jak -ing [końcówka fleksyjna imiesłowu czynnego], of 'od, przez, do (przyimek)', be 'być' (jako słowo posiłkowe), it 'to' (jak np. w It's raining 'pada deszcz') i that 'że' (jak w I know that she left 'wiem, że wyszła'), różnice są oczywiście uderzające. [...] Niemniej wszystkie te różnice są kwestią stopnia i z łatwością odnajdujemy przykłady pośrednie. Wyznaczniki leksykalne np. różnią się ogromnie między sobą pod względem konkretności znaczenia (jak w sekwencji [od najbardziej do

11 Pozostałe trzy wymiary nondiscreteness to: zdroworozsądkowy/intuicyjny (a nie: dychotomiczny) model sądów kategoryzacyjnych, prototypowy (a nie: dystynktywny) model kategorii i holistyczny (a nie: komponencjalny) model systemu językowego.

12 Inne dychotomie to m.in.: synchronia - diachronia, morfologia - składnia, semantyka - pragmatyka, homonimia - polisemia, konotacja - denotacja. Te i inne Langacker uważa za „fałszywe dychotomie" (Langacker 1987: 18). 


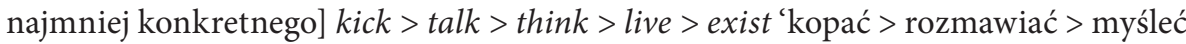
$>$ żyć > istnieć'), a także pod względem semantycznego uszczegółowienia (giraffe > $>$ mammal $>$ animal $>$ organism $>$ thing 'żyrafa $>$ ssak $>$ zwierzę $>$ organizm $>$ rzecz') (ibid.: 18-19).

Co więcej, Langacker stwierdza, że „jeśli nie wszystkie” (ibid.: 18), to z pewnością większość tzw. formantów gramatycznych ma swoje znaczenie, wobec czego nie sposób dowieść, że czasowniki modalne, kwantyfikatory czy przyimki mają w sobie mniej treści semantycznej niż takie typowe wyznaczniki leksykalne, jak rzeczownik rzecz i czasownik mieć.

W nowszej pracy Langackera (2008) termin continuum zostaje expressis verbis przywołany 9 razy, $\mathrm{z}$ tego pięciokrotnie w kontekście kontinuum gramatyki i leksyki (ibid.: 96, 161, 219, 237, 263) ${ }^{13}$. Podobnie jak w przywoływanej już pracy (1987) mamy listę nieuprawnionych twierdzeń językoznawczych; wszystkie oparte są na założeniu, że zjawiska językowe nie mają natury ciągłej. Langacker wylicza ich 10 (wśród nich dychotomiczny podział na diachronię i synchronię oraz ostry podział na komponenty języka, takie jak fonetyka, fonologia, morfologia, składnia itd.; Langacker 2009: 29-30). Towarzyszy temu wszak uwaga, że nie oznacza to, by „wszystko w języku miało charakter ciągły [ang. continuous]", lub że w opisie językoznawczym nie mają zastosowania nieciągłe przedstawienia (ang. discrete representations) zjawisk językowych.

Oto dwie z wielu jego zdroworozsądkowych ilustracji tego, jak pogodzić te dwa stanowiska, tzn. tezę, że język ma z zasady naturę kontinuum, i tezę, że to kontinuum nie wyklucza możliwości wyodrębniania w nim / z niego elementów, kategorii czy relacji nieciągłych.

Przykład 1. Postrzeganie zdarzenia (ang. event) Langacker porównuje do oglądania filmu:

Doświadczalne pojmowanie zdarzenia przypomina oglądanie filmu, w odróżnieniu od oglądania serii zdjęć [fotografii]. Zdarzenie jest koncepcją ciągłą [ang. continuous], chociaż każdy odcinek czasu składa się z relacji prostej [ang. discrete]. Te relacje składowe - które nazywamy stanami - nie są ani wyodrębnione, ani rozpatrywane osobno na poziomie świadomości. Przeciwnie, zdarzenie jest konceptualizowane jako nieprzerwanie rozwijające się w czasie, przy czym każdy jego stan w naturalny sposób wynika ze stanu poprzedniego. Tę ciągłość [ang. continuity] przedstawia symbol w kształcie klina (>) [na diagramach i rysunkach], który jednocześnie znosi nieciągłość [ang. discreteness], mylnie sugerowaną przez statyczne rysunki (ibid.: 151).

13 Poza tym Langacker mówi o kontinuum leksyki, morfologii i składni (2008: 15), o kontinuum wyrażeń, które nazywa expressives (ibid.: 475) i o kontinuum gramatyki i dyskursu (ibid.: 498). Uwaga: w polskim tłumaczeniu przez kontinuum zostaje czasami oddane także angielskie słowo gradation 'dosł. gradacja' (np. ibid.: 5 i 20 vs Langacker 2009: 20 i 39). To jedynie podkreśla, że Langackerowskie kontinuum pozostaje w ścisłym i nierozerwalnym związku ze stopniowalnością. 
Przykład 2. Kategorię Langacker porównuje do łańcucha górskiego:

Załóżmy, że kategoria jest jak łańcuch górski, a szczyty odpowiadają jej elementom. Szczyty nie są bytami wyraźnie wyodrębnionymi [ang. discrete], lecz płynnie [ang. continuous] przechodzą jeden w drugi, wznosząc się na różne wysokości ze wspólnej podstawy. [...] Pomimo tej zasadniczej ciągłości [ang. continuity] błędem byłoby postulować zupełny brak odrębności [ang. discreteness]. Wszak łańcuch górski ma szczyty i charakteryzuje go pewien specyficzny układ [...]. Bezsensowne byłoby zanegować istnienie tej struktury lub zakazać opisywania jej za pomocą terminów sugerujących odrębność [ang. discreteness] (rzeczowników policzalnych, jak szczyt, dolina, grań itp.) (ibid.: 298-299).

Podsumujmy. Obydwa przykłady ilustrują to, co już wcześniej przypisaliśmy kontinuum $\mathrm{w}$ rozumieniu Langackera: ciągłość gramatyki i leksyki opiera się na płynności granic wyznaczników gramatycznych i leksykalnych, a ta płynność prowadzi do wzajemnego przenikania się i stopniowego przechodzenia leksyki w gramatykę, co powoduje, że między prototypowymi przykładami gramatyki i leksyki znajdują się przykłady pośrednie, w których gramatyka spotyka się z leksyką w różnym stopniu i pod różnymi względami.

To, że można wskazać jednoznaczny przykład szczytu, doliny i grani, nie oznacza, że wiemy z precyzją właściwą odrębności, w którym miejscu grań przechodzi w szczyt ani czym różnią się turnie od szczytów albo doliny od kotlin, a te od kotłów. Równie trudno o pewność przy stwierdzaniu, w którym momencie wyodrębnione klatki stają się filmem. Wrażenie oglądania filmu występuje już przy odtwarzaniu 15 klatek na sekundę, ale czy ta 1 sekunda i te 15 klatek to już film?

Te same pytania znajdują zastosowanie w przypadku gramatykalizacji: angielski przysłówek always i końcówka fleksyjna -ed pełnią dziś funkcje gramatyczne, ale pierwsze było kiedyś wyrażeniem leksykalnym, a drugie nie było aż tak gramatyczne, jak jest dzisiaj. Bez względu na to, jaka miałaby być odpowiedź na pytanie, czym jest leksyka i gramatyka, mamy do czynienia z ciągłością, płynnością i stopniowalnością leksykalno-gramatycznego kontinuum. 


\section{Literatura}

BresnAN J., 2015, Lexical-Functional Syntax, wyd. 2, Oxford.

FILAR D., 2015, Język jako wielka narracja: teoria narracyjności w semantyce, „Biuletyn Polskiego Towarzystwa Językoznawczego" LXXI, s. 9-26.

Filar D., Łozowski P., 2018, Gramatykalizacja i leksykalizacja pojęć a językowy obraz świata, czyli szkic o ekwiwalencji kognitywnej, „Etnolingwistyka” 30, s. 69-89.

Filar D., Łozowski P., 2019, On cognitive Equivalence: Grammaticalisation and Lexicalisation in the Linguo-cultural Picture of the World, „Etnolingwistyka” 31, s. 69-88.

Hwaszcz K., KęDzierska H., 2018a, The Rise of an Indefinite Article in Polish: An Appraisal of Its Grammaticalisation Stage. Part 1, „Studies in Polish Linguistics” 13, nr 2, s. 93-112, [on-line:] http://dx.doi.org/10.4467/23005920SPL.18.005.8744.

Hwaszcz K., KęDzierska H., 2018b, The Rise of an Indefinite Article in Polish: An Appraisal of Its Grammaticalisation Stage. Part 2, „Studies in Polish Linguistics” 13, nr 3, s. 145-166, [on-line:] http://dx.doi.org/10.4467/23005920SPL.18.007.9256.

ISJP: M. Bańko (red.), Inny słownik języka polskiego, Warszawa 2000.

KĘPIŃsKa A., WiniarsKa-GórsKa I., 2015, Ciągłość i zmiana w języku w świetle polskich szesnastowiecznych przekładów Ewangelii, „Biuletyn Polskiego Towarzystwa Językoznawczego" LXXI, s. 223-239.

KiklewiCz A., 2017, Nieokreśloność a kwantyfikacja: współdziałanie kategorii semantycznych, „LingVaria” nr 1 (23), s. 43-6o, [on-line:] http://dx.doi.org/10.12797/LV.12.2017.23.03.

Kubicka E., 2018, Czy mówiąc prostszym językiem, mówimy prościej? Formalnie narzędnikowe frazy charakteryzujące mówienie, „LingVaria” nr 1 (25), s. 79-90, [on-line:] http:// dx.doi.org/10.12797/LV.13.2017.25.06.

KuryŁowiCZ J., 1965/1975, The Evolution of Grammatical Categories, „Diogenes” 13, nr 51, s. 55-71, [on-line:] https://doi.org/10.1177\%2F039219216501305105.

LANGACKer R.W., 1987, Foundations of Cognitive Grammar, t. I: Theoretical Prerequisites, Stanford.

LANGacker R.W., 2008, Cognitive Grammar. A Basic Introduction, Oxford.

LANGACKer R.W., 2009, Gramatyka kognitywna. Wprowadzenie, tłum. E. Tabakowska i in., Kraków.

LANGACKer R.W., 2016, Nominal Structure in Cognitive Grammar. The Lublin Lectures, red. A. Głaz, H. Kowalewski, P. Łozowski, Lublin.

LAngacker R.W., 2017, The Functions of Trees, [w:] P. Łozowski, A. Głaz (red.), Route 66: from Deep Structures to Surface Meanings. A Festschrift for Henryk Kardela on his $66^{\text {th }}$ Birthday, Lublin, s. 73-92.

Luto-KamińsKa A., 2017, Norma językowa w polszczyźnie historycznej, „Biuletyn Polskiego Towarzystwa Językoznawczego" LXXIII, s. 144-16o.

Łozowski P., 2008, Language as Symbol of Experience: King Alfred's cunnan, magan, and motan in a Panchronic Perspective, Lublin.

Niewiara A., 2017, Słowa klucze kultury jako nazwy pojęć wyrazistych o wysokim stopniu utrwalenia a zagadnienia synonimii leksykalnej, „LingVaria” nr 1 (23), s. 233-252, [on-line:] http://dx.doi.org/10.12797/LV.12.2017.23.16.

NSJP: E. Sobol (red.), Nowy słownik języka polskiego PWN, Warszawa 2002.

NSJPDun: B. Dunaj (red.), Nowy słownik jezzyka polskiego, Warszawa 2005.

PSWP: H. Zgółkowa (red.), Praktyczny słownik współczesnej polszczyzny, Poznań 1994-2005. 
SJP: Słownik języka polskiego, [on-line:] https://sjp.pwn.pl.

SJPD: W. Doroszewski (red.), Słownik języka polskiego, Warszawa 1958-1969.

Sовотка P., Ż̈вошsка M., 2017, Wyodrębnianie, dekodowanie i klasyfikacja historycznych jednostek języka, „LingVaria” nr 2 (24), s. 113-134, [on-line:] http://dx.doi.org/10.12797/ LV.12.2017.24.07.

Topolińska Z., 2018, 'Transforma zdaniowa' - próba interpretacji, „LingVaria” nr 2 (26), s. 39-46, [on-line:] http://dx.doi.org/10.12797/LV.13.2018.26.03.

USJP: S. Dubisz (red.), Uniwersalny słownik języka polskiego, Warszawa 2003.

WASILEWSKA K., 2018, Frekwencja oraz funkcje przyimków złożonych i wtórnych w sprawozdaniach administracyjnych, „LingVaria” nr 1 (25), s. 273-291, [on-line:] http://dx.doi. org/10.12797/LV.13.2017.25.20.

\section{In Search of the Continuum of Grammar and Lexis: An Example of Grammaticalization Summary}

We refer to the phenomenon of grammaticalization, and ask the question whether it is justified to talk about the continuum of grammar and lexis in language, and if it is, then in what sense and in what degree. In the case of grammaticalization, we follow Jerzy Kuryłowicz's interpretation, and in the case of the notion of continuum, we refer to the findings of Ronald Langacker, and take into consideration a series of possible interpretations/models of his understanding of the continuity of grammar and lexis. 